\title{
РОЛЬ МУЛЬТИМЕДІЙНИХ ТЕХНОЛОГІЙ У ПОЛІПШЕННІ ВИКЛАДАННЯ ТА ЗАСВОЄННЯ ПАТОФІЗІОЛОГІЇ
}

\author{
Ю. М. Вепрюк, Ю. Є. Роговий \\ Вищий державний навчальний заклад Украӥни \\ “Буковинський державний медичний університет”, м. Чернівці
}

\section{THE ROLE OF MULTIMEDIA TECHNOLOGIES IN IMPROVING OF LEARNING AND MASTERING PATHOPHYSIOLOGY}

\author{
Yu. M. Vepriuk, Yu. Ye. Rohovyi \\ Bukovynian State Medical University, Chernivtsi
}

\begin{abstract}
У представленій публікації пропонується впровадити у навчальний процес нові розробки мультимедійних технологій, у яких об’єднані текстова, графічна, відеоінформація та анімація складних патологічних процесів, станів і реакцій, що дасть можливість істотно поліпшити засвоєння провідної теоретичної дисципліни 3 домінуючим напруженням таких сфер людської свідомості, як мислення та інтелект, і забезпечити цілеспрямоване, систематичне й послідовне впровадження в практику оригінальних, новаторських способів, що охоплюють цілісний навчальний процес від визначення його мети до очікуваних результатів.
\end{abstract}

In the present publication it is introduced the learning process of the development of new media technologies, which combine text, graphics, animation and video information complex pathological processes, conditions and reactions, which will allow to significantly improve the assimilation of the leading theoretical discipline with the dominant strain of spheres of human consciousness as thought and intellect and provide targeted, systematic and consistent implementation in practice of original, innovative ways of covering holistic educational process of defining its purpose to the expected results.

Вступ. Провідна мета навчально-методичної роботи медичного університету полягає у підготовці спеціалістів, здатних в умовах практичної охорони здоров’я клінічно мислити, оперативно приймати рішення як у типових, так і в нестандартних ситуаціях, при цьому рівень підготовки фахівців у галузі медицини повинен характеризуватися динамікою переходу з першого (“знаю”) та другого (“знаю як”) рівнів піраміди Джорджа Міллера до третього (“демонструю”) та четвертого (“роблю”) рівнів [2, 3, 6]. У забезпеченні такої динаміки істотну роль можуть відіграти нові розробки мультимедійних технологій, у яких об’єднані текстова, графічна, відеоінформація та анімація складних патологічних процесів, патологічних станів і патологічних реакцій, що дасть можливість істотно поліпшити засвоєння провідної теоретичної дисципліни з домінуючим напруженням таких сфер людської свідомості, як мислення та інтелект, і забезпечити цілеспрямоване, систематичне й послідовне впровадження в практику оригінальних, новаторських способів, що

(с) Ю. М. Вепрюк, Ю. Є. Роговий охоплюють цілісний навчальний процес від визначення його мети до очікуваних результатів $[4,7]$.

Мета даної публікації полягала в презентації нових розробок мультимедійних технологій для поліпшення викладання провідної теоретичної дисципліни - патофізіології.

Основна частина. Теоретичний фундамент клінічного мислення майбутнього лікаря формується в основному при вивченні патофізіології, що потребує в студентів з перших кроків освоєння цього предмета інтенсивної роботи таких сфер людської свідомості, як мислення (поняття, судження, умовивід) та інтелект (аналіз, синтез, абстракція, конкретизація, узагальнення) [5, 8]. У вирішенні цієї проблеми істотну роль можуть відіграти нові розробки мультимедійних технологій [1], які включають такий перелік:

1. Нозологія. Типовий патологічний процес.

2. Патогенез. Вадне коло.

3. Патофізіологія КЛР. Номограма SiggaardAndersen.

4. Патофізіологія КЛР. Хлоридне зміщення Хамбургера. 
5. Патофізіологія периферійного кровообігу. Артеріальна гіперемія.

6. Патофізіологія периферійного кровообігу. Венозна гіперемія.

7. Патофізіологія периферійного кровообігу. Ішемія.

8. Патофізіологія гемостазу. Тромбоемболія легеневої артерії.

9. Лейкоцитози і лейкопенії. Токсична зернистість нейтрофілів.

10. Лейкоцитози і лейкопенії. Тільця Бара.

11. Лейкоцитози і лейкопенії. LE-феномен.

12. Лейкоцитози і лейкопенії. Гіпер- та гіпосегментація ядер нейтрофілів.

13. Гарячка. Febris recurens.

14. Гемолітичні анемії. Анемія Мінковського Шофара.

15. Гемолітичні анемії. Еліпсоцитоз.

16. Гемолітичні анемії. Лейко-еритробластичне співвідношення.

17. Патофізіологія печінки. Білірубінові камені жовчного міхура.

18. Гемолітичні анемії. Стоматоцитоз.

19. Гемолітичні анемії. Акантоцитоз.

20. Гемолітичні анемії. Дрепаноцити.

21. Гемолітичні анемії. Таласемія.

22. Гемолітичні анемії. Тільця Гейнца.

23. Запалення. Пентада Цельса - Галена.

24. Запалення. Крайове розміщення, адгезія i трансміграція нейтрофіла.

25. Імунопатологія. Вірус СНІДу.

26. Лейкози. Хронічний мієлолейкоз.

27. Лейкози. Філадельфійська хромосома.

28. Гемобластози. Клітина Березовського Штернберга.

29. Лейкоцитози і лейкопенії. Атиповий мононуклеар.

30. Патофізіологія зовнішнього дихання. Проба Вотчела - Тифно.

31. Патофізіологія зовнішнього дихання. РДС.

32. Патофізіологія нирок. Мембранозно-проліферативний гломерулонефрит.

33. Патофізіологія нервової системи. Ядерна жовтяниця.

34. Патофізіологія ендокринної системи. Базедова хвороба.

35. Шок. Механізм “pooling” у гемодинамічну стадію шоку.

36. Патофізіологія ВСО. Проба Мак-Клюра Олдрича.

37. Патофізіологія ВСО. Синдром Кона.
38. Ушкодження клітини. Апоптоз.

39. Гемобластози. Мієломна хвороба.

40. Патофізіологія ВСО. Гіперкаліємія.

41. Патофізіологія ВСО. Гіпокаліємія.

42. Старіння. Ліміт Хейфліка.

43. Недостатність зовнішнього дихання. Дихання Чейна - Стокса.

44. Недостатність зовнішнього дихання. Гаспінг дихання.

45. Недостатність зовнішнього дихання. Дихання Біота.

46. Патофізіологія гемостазу. Хвороба Віллебранда.

47. Патогенез. Шистосоматоз.

48. Патогенез. Опісторхоз (котячий сибірський сисун).

49. Анемії внаслідок порушення кровотворення. Тільця Кебота.

50. Патофізіологія ендокринної системи. Синдром Іценка - Кушинга.

Для прикладу наводимо демонстрацію венозної гіперемії за умов порушень периферійного кровообігу (рис. 1), крайового розміщення, адгезії і трансміграції нейтрофіла за розвитку запалення (рис. 2), та механізму розвитку спадкової гемолітичної анемії Мінковського - Шофара (рис. 3).

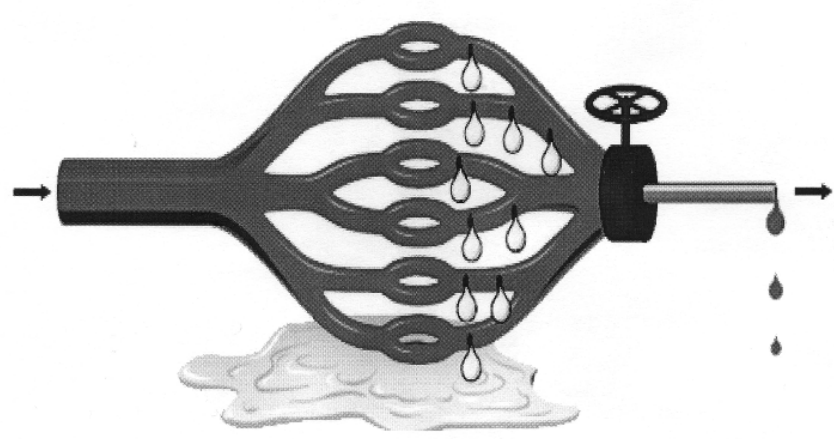

Рис. 1. Патофізіологія периферійного кровообігу. Венозна гіперемія.

Впровадження у навчальний процес нових розробок мультимедійних технологій дасть можливість досягти реалізації провідних інтересів патофізіології щодо пізнання глибоких загальних закономірностей розвитку хвороби, передхвороби, забезпечити провідну роль патофізіології у формуванні в студентів основ клінічного мислення та виконувати функцію методології клінічних дисциплін із можливістю істотного поліпшення якості навчального процесу з провідної теоретичної дисципліни. 


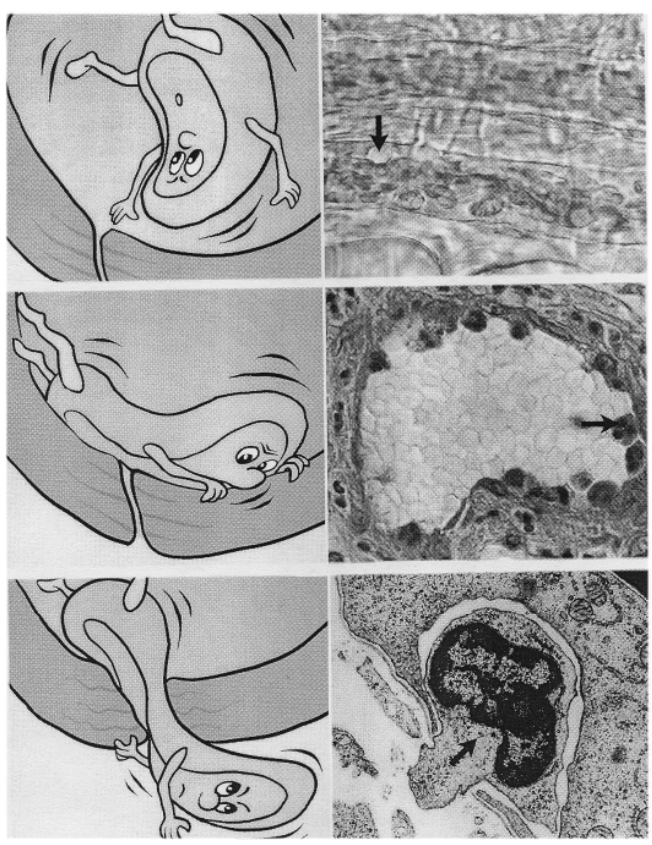

Рис. 2. Запалення. Крайове розміщення, адгезія і трансміграція нейтрофіла.

Висновок. У представленій публікації головну увагу зосереджено на тому, що патологічна фізіо-

\section{Список літератури}

1. Методичні рекомендації з проведення II етапу Всеукраїнської студентської олімпіади 2014/2015 навчального року серед студентів вищих медичних університетів III-IV рівнів акредитації із навчальної дисципліни “Патологічна фізіологія" / [Т. М. Бойчук, Ю. Є. Роговий, Л. О. Філіпова та ін.]. - Чернівці : Букрек, 2015. - 64 с.

2. Мруга М. Р. Оцінка клінічної компетентності студентів медичних навчальних закладів за допомогою стандартизованих пацієнтів / М. Р. Мруга, І. Є. Булах // Медична освіта. - 2000. - № 4. - С. 14-19.

3. Досвід навчально-методичної роботи кафедри патологічної фізіології / Ю. Є. Роговий, В. Ф. Мислицький, Л. О. Філіпова [та ін.] // Медична освіта. - 2001. № 3. - С. 38-40.

4. Роговий Ю. Є. Роль альтернативних методів навчання при викладанні теоретичних та клінічних медичних дисциплін / Ю. Є. Роговий, А. В. Бочаров, Р. М. Кобилянська // Медична освіта. - 2003. - № 1. - С. 22-24.

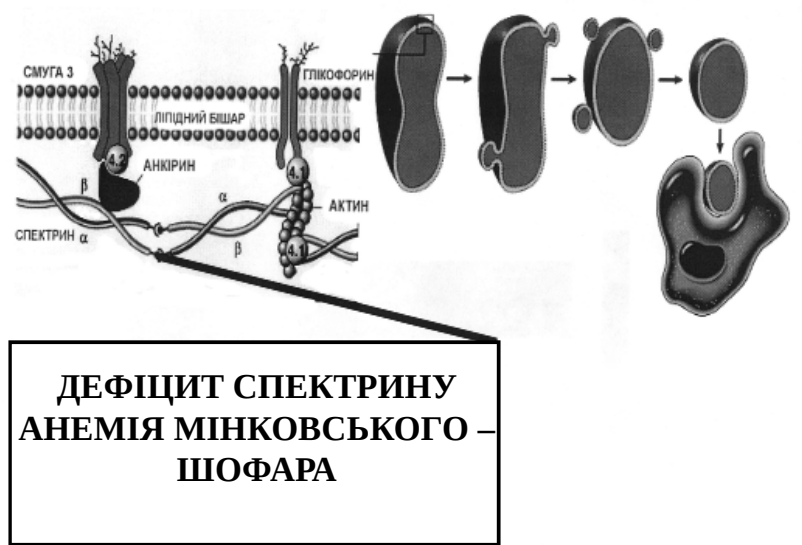

Рис. 3. Гемолітичні анемії. Анемія Мінковського Шофара.

логія як фундамент експериментальної медицини повинна відігравати провідну роль у формуванні в студентів основ клінічного мислення та виконувати функцію методології клінічних дисциплін, що досягається впровадженням у навчальний процес нових розробок мультимедійних технологій, у яких об'єднані текстова, графічна, відеоінформація та анімація складних патологічних процесів, патологічних станів та патологічних реакцій.

5. Роль центральної науково-дослідної лабораторії у покращанні навчально-методичної роботи кафедри патологічної фізіології / Ю. Є. Роговий, Л. О. Філіпова, В. А. Дорошко [та ін.] // Медична освіта. - 2012. № 3. - С. 84-85.

6. Роль V Міжнародного конгресу патофізіологів (ISP 2006) у поліпшенні викладання та засвоєння провідної теоретичної дисципліни / Ю. Є. Роговий, Л. О. Філіпова, Л. Г. Архіпова, І. Л. Муравйова // Медична освіта. 2007. - № 4. - С. 22-24.

7. Історія та сьогоднішні досягнення кафедри патологічної фізіології Буковинського державного медичного університету / Ю. Є. Роговий, Л. О. Філіпова, В. А. Дорошко [та ін.] // Бук. мед. вісник. - 2015. - Т. 19, № 1 (73). - C. 268-272.

8. Rohovyy Yu.Ye. Essential pathophysiology for medical students / Yu. Ye. Rohovyy, L. O. Filipova, V. A. Doroshko. - Chernivsti : Misto, 2011. - 296 р. (ГРИФ МОН України № 1/11-7022 від 29.07.10). 